\title{
Adhesion Ability and Cytotoxic Evaluation of Lactobacillus Strains Isolated from Malaysian Fermented Fish (Pekasam) on Ht-29 and Ccd-18Co Intestinal Cells
}

(Keupayaan Perlekatan dan Penilaian Sitotoksik Strain Lactobacillus Dipencilkan daripada Ikan Pekasam Malaysia ke atas Sel Usus Ht-29 dan Ccd-18Co)

\author{
IDA MURYANY, Hing HiANG LiAn, INA-SALWANY, AHMAD ROHI GHAZALI, \\ MOHDZAMRI-SAAD \& NOR FADILAH RAJAB*
}

\begin{abstract}
Bacterial adhesion to host cells is the most important probiotic character. However, the adhesion of probiotic should not affect the viability of the host cells. In this study, Lactobacillus plantarum strain L8, Lactobacillus plantarum strain L20 and Lactobacillus pentosus strain $S 1$ were tested for their cytotoxic effects through MTT assay and their ability to adhere and colonize on HT-29 and CCD-18Co intestinal cells as detected microscopically using light microscopy and Scanning Electron Microscopy (SEM). No cytotoxicity effects were observed on both intestinal cells following $24 \mathrm{~h}$ treatment with all Lactobacillus strains. Additionally, all strains demonstrated strong adhesive activity where more than 100 bacteria adhered to both intestinal cells although differences in the adhesion scores observed among different strains. The adhesion as observed via SEM showed an autoagreggative pattern and adhered as clusters on the surface of both intestinal cells. In conclusion, all three Lactobacillus strains are non-cytotoxic to both cells with strong adhesion ability on intestinal cells and this study also proved that Malaysian fermented fish are good source of probiotic bacteria.
\end{abstract}

Keywords: Adhesion; Lactobacillus; probiotics; scanning electron microscopy (SEM)

\section{ABSTRAK}

Perlekatan bakteria pada sel perumah merupakan kriteria probiotik yang paling penting. Walau bagaimanapun, perlekatan probiotik mestilah tidak menjejaskan keviabelan sel perumah. Dalam kajian ini, Lactobacillus plantarum strain L8, Lactobacillus plantarum strain L20 dan Lactobacillus pentosus strain S1 telah diuji kesan sitotoksik ke atas sel usus melalui ujian MTT dan keupayaan mereka untuk melekat dan mengkoloni sel usus HT-29 dan CCD-18Co seperti yang dikesan secara mikroskopik menggunakan mikroskop cahaya dan pengimbasan mikroskop elektron (SEM). Keputusan kajian menunjukkan kesan sitotoksik tidak terdapat pada kedua sel usus berikut rawatan 24 jam dengan semua strain Lactobacillus. Selain itu, semua strain menunjukkan aktiviti perlekatan yang kuat untuk kedua sel usus walaupun terdapat perbezaan skor perlekatan pada strain yang berbeza. Paten perlekatan di bawah SEM menunjukkan corak autoagregatif dan melekat secara kluster pada permukaan kedua-dua sel usus. Kesimpulannya, kesemua strain Lactobacillus yang dikaji adalah tidak sitotoksik pada kedua sel dengan mempamerkan keupayaan perlekatan yang kuat pada sel usus.

Kata kunci: Lactobacillus; pengimbasan mikroskop elektron (SEM); perlekatan; probiotik

\section{INTRODUCTION}

Interest in the discovery of new probiotics from natural and sustainable resources for health and civilization development is growing. The origins, non-pathogenicity characteristic and in vitro adherence ability to the intestinal cells of the strain are the most important criteria to be considered a probiotic (Coconier et al. 1992). Lactobacillus is one of the most characterized probiotic microorganisms (Holm 2003) because of its ability to provide therapeutic benefits by producing lactic acid and antibacterial substances to stimulate and modulate the host immune system (Liong 2008). Lactobacilli are Gram-positive anaerobic or facultative aerobic bacteria that can be isolated from different resources (Wang et al. 2009). They are non-pathogenic and non-spore-forming rods in morphology with the majority inhabiting the intestinal tract cavity. Currently, the genus Lactobacillus has been widely used as a probiotic source (Pringsulaka et al. 2015) as it has several health-promoting effects and claims, such as improved gastrointestinal immune response (Christensen et al. 2002), prevention of diarrhea (Biller et al. 1995), treatment of colon cancer (Koop-Hoolithan 2001), attenuate hypertension (Yap et al. 2016) and many others. Probiotic is designated by FAO/WHO (2002) as a live microorganism that offers health benefits to host cells when administered in sufficient quantity. One of the important benefits of probiotics to humankind is their ability to colonize the gastrointestinal tract (Lee et al. 2017).

The excellent capacity to adhere to epithelial cells and mucosal surfaces has been suggested to be an important step of colonization as it could protect the gastrointestinal environment from pathogens by competing for the receptor 
sites on the cell surface (Nader-Macias et al. 2007). Bacterial adhesion is a complex process of innate and adaptive interactions involving direct contact between the bacterial cell membrane and the receptor of host cells on the epithelial surface (An \& Friedman 2000). Chang et al. (2004) showed that adhesion is one of the strategies used by bacteria to stabilize in different ecological niches by competing for nutrients with other bacteria. Other studies reported that the adhesion ability of probiotic bacteria to intestinal cells could prevent the attachment of pathogens, thus protecting the intestinal tract from infection (Lee et al. 2000). Probiotic bacteria can successfully inhibit the adhesion of pathogenic microorganisms, such as Salmonella, Escherichia coli, Staphylococcus aureus and Clostridium difficile (Collado et al. 2007). Ayeni et al. (2011) isolated Lactobacillus paracasei and Lactobacillus brevis from Nigerian traditional fermented dairy foods and they showed good adhesion ability to Caco-2 and HT-29 epithelial intestinal cells. Similarly, Ren et al. (2014) reported that the Lactobacillus plantarum strain CGMCC 1.557 isolated from vegetable showed the most adhesion and produced the highest quantity of exopolysaccharides among eight other Lactobacillus strains.

Currently, both health and industrial sectors are showing great interest in the search for new strains of probiotics with functional properties, especially from traditional fermented foods (Ayeni et al. 2011). Nonindustrialized countries offer a variety of traditional fermented foods, which comprise a pool of new strains with excellent functional properties (Thapa et al. 2006). In vitro studies on cell lines have been used as an approach to evaluating various characteristics, such as anticancer activity (Hilde et al. 2003), stimulation of the immune system (Isolauri et al. 2001), antimicrobial activity to inhibit the growth of pathogenic bacteria (Ghani et al. 2018) and protection and stabilization of gut microflora (Gibson et al. 1997) by potentially probiotic bacteria. Evaluating the adherence activity of bacteria using human epithelial cell lines as an in vitro model has been a common procedure in the preliminary screening of potential probiotic strains. Scanning electron microscopy (SEM) is one of the important tools used to investigate membrane integrity. In the present study, the cytotoxicity potential and adherence capability of $L$. plantarum strain L8, $L$. plantarum strain L20 and L. pentosus strain S1 isolated from Malaysian fermented fish (pekasam) on HT-29 and CCD-18Co intestinal cells were evaluated. This study aims to provide beneficial information on the safety and potential probiotic activity of all strains isolated locally from Malaysian fermented fish.

\section{MATERIALS AND METHODS}

\section{BACTERIAL STRAINS AND GROWTH CONDITIONS}

Three Lactobacillus strains were used in this study; $L$. plantarum strain L8, L. plantarum strain L20 and L. pentosus strain $\mathrm{S} 1$ were identified using GenBank with accession numbers KT591874, KT 591875 and KT920464 (Ida Muryany et al. 2016), respectively. All the strains were isolated from the Malaysian fermented fish (from species Johnius Belangerii and Thynnichthys thynnoides) known as pekasam. Lactobacillus strains were grown at $37^{\circ} \mathrm{C}$ for $48 \mathrm{~h}$ in MRS agar (deMan, Rogosa and Sharpe) (Oxoid, Australia) before being transferred to the MRS broth (Oxoid, Australia) for overnight incubation at $37^{\circ} \mathrm{C}$.

\section{INTESTINAL CELL LINES AND CULTURE CONDITIONS}

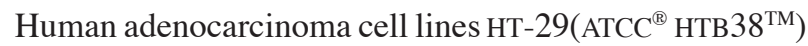
and human colonic fibroblast CCD-18Co ( $\mathrm{ATCC}^{\circledR} \mathrm{CRL}-$ $1459^{\mathrm{TM}}$ ) were cultured in McCoy's 5A Medium (Sigma, USA) and Eagle's Minimum Essential Medium (Sigma, USA), respectively. Both media were supplemented with $10 \%$ (v/v) fetal bovine serum (FBS; Sigma, USA) and $100 \mu \mathrm{g} \mathrm{mL}^{-1}$ of penicillin-streptomycin (Sigma, USA). Both cells were cultured in Nunc ${ }^{\mathrm{TM}}$ tissue culture flasks (Thermo Fisher Scientific, USA) at $37^{\circ} \mathrm{C}$ in a $5 \% \mathrm{CO}_{2}$ using a humidified incubator (Binder, USA). The cell culture medium was replaced with fresh medium every other day.

\section{CYTOTOXICITY ACTIVITY OF PROBIOTICS USING MTT ASSAY}

The viability testing of the cells incubated with the bacteria was performed using the modification method by Mario et al. (2014) via the determination of metabolic activity of the mitochondrial lactate dehydrogenase enzyme (Ivec et al. 2007; Mosmann 1983). HT-29 and CCD-18Co cells were seeded separately at $10^{5}$ cells per well using $\mathrm{NUNC}^{\mathrm{TM}}$ 96 flat bottom well plates (Thermo Scientific USA) and were incubated in a humidified incubator supplemented with $5 \% \mathrm{CO}_{2}$ atmosphere at $37^{\circ} \mathrm{C}$ for $24 \mathrm{~h}$. Monolayer cells were washed twice with sterile PBS and added with $100 \mu \mathrm{L}$ of bacteria suspension at $10^{9}, 10^{8}, 10^{7}, 10^{6}, 10^{5}$ and $10^{4} \mathrm{CFU} \mathrm{mL} \mathrm{mL}^{-1}$ concentrations in a medium without FBS and antibiotics (incomplete medium). Lactobacillus strains L8, L20, and S1 suspensions were each added in triplicate to separate wells and plates and incubated for $4 \mathrm{~h}$ in $5 \% \mathrm{CO}_{2}$ at $37^{\circ} \mathrm{C}$ to allow bacteria to attach to cell monolayers. The cells were washed three times with sterile PBS at $37^{\circ} \mathrm{C}$ after incubation to remove non-attached bacteria. After washing, $100 \mu \mathrm{L}$ of fresh incomplete medium was added to the cells and plates and incubated for $24 \mathrm{~h}$ in a humidified incubator supplemented with $5 \% \mathrm{CO}_{2}$ at $37^{\circ} \mathrm{C}$. The cells that were not treated with additional bacteria were used as negative controls, while cells treated with hydrogen peroxide was used as a positive control. The medium was discarded after incubation, and the wells with monolayer cells were washed twice with sterile PBS at $37{ }^{\circ} \mathrm{C}$. Then, $200 \mu \mathrm{L}$ of fresh incomplete medium and $20 \mu \mathrm{L}$ of $0.5 \%$ $(\mathrm{w} / \mathrm{v})$ MTT solution (Sigma USA) were added to each well. After the addition of the MTT solution, the plates were incubated further for $4 \mathrm{~h}$ in the incubator supplemented with $5 \% \mathrm{CO}_{2}$ at $37^{\circ} \mathrm{C}$. The medium with MTT solution was discarded and $200 \mu \mathrm{L}$ of dimethyl sulfoxide (Sigma USA) 
was added to each well to solubilize the formazan crystals formed, followed by incubation at room temperature for $30 \mathrm{~min}$. The absorbance was measured spectrometrically after incubation at $570 \mathrm{~nm}$ using the microplate reader (Tecan Switzerland).

\section{ADHESION DETERMINATION}

The adhesion abilities of the Lactobacillus strains were identified according to the method described previously by Jacobsen et al. (1999). Both cell monolayers, HT-29 and CCD-18Co intestinal cells ( $10^{5}$ cells $\mathrm{mL}^{-1}$ in 6 wells), were washed twice with PBS and $3 \mathrm{~mL}$ of incomplete medium was added to each well. The wells were incubated for 30 min before the inoculation of bacteria. Then, $100 \mu \mathrm{L}$ of overnight culture of bacteria with $10^{8} \mathrm{CFU} \mathrm{mL} \mathrm{m}^{-1}$ was added to each well containing the monolayer cells. After incubation for $3 \mathrm{~h}$ at $37^{\circ} \mathrm{C}$, all the wells were washed three times with PBS to release the unbound bacteria. The cells were then fixed with $3 \mathrm{~mL}$ of methanol (Merck Germany) and incubated for $10 \mathrm{~min}$ at room temperature. The cells were stained with $3 \mathrm{~mL}$ of Giemsa stain solution (1:50) (Merck Germany) after the removal of methanol and left for $30 \mathrm{~min}$ at room temperature. The wells were washed three times in the buffer solution to remove excess stain. The plates were air dried and examined under an inverted microscope (Leica Germany). The number of Lactobacilli that adhered was counted in 20 randomly picked microscopic fields for each intestinal cell. The strain was considered non-adhesive when the total number of bacteria in the 20 microscopic fields was less than 40 bacteria, adhesive when the number was between 41 and100 and strongly adhesive when more than 100 (Jacobsen et al. 1999).

\section{SCANNING ELECTRON MICROSCOPY}

An observation was made by SEM for a qualitative examination of the adhesion. Coverslips (13 mm) (Sarstedt USA) were placed at the bottom of the 24-well tissue culture plates (Thermo Fisher Scientific USA). Both the HT-29 and CCD-18Co cells (about $2 \times 10^{5}$ cells $\mathrm{mL}^{-1}$ ) were seeded and incubated at $37^{\circ} \mathrm{C}$ in $5 \% \mathrm{CO}_{2}$ until they reached $80 \%-90 \%$ confluency. The cell monolayers were washed twice with PBS (pH7.2) before a $900 \mu \mathrm{L}$ antibiotic-free medium was added. Overnight cultures of Lactobacillus strains in MRS broth were centrifuged for $10 \mathrm{~min}$ at $1008 \times \mathrm{g}$ and the pellets were re-suspended in an antibiotic-free medium to

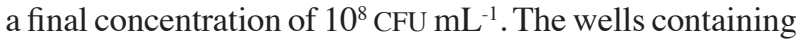
monolayer cells and $100 \mu \mathrm{L}$ bacteria suspensions were incubated for $4 \mathrm{~h}$ at $37^{\circ} \mathrm{C}$ in a humidified incubator supplemented with $5 \% \mathrm{CO}_{2}$. After incubation, the HT-29 and CCD-18Co cell monolayers (in a different well) were washed three times with $0.1 \mathrm{M}$ phosphate buffer $(\mathrm{pH} 7.2)$ to release any unbound bacteria. The cells were fixed with $2.5 \%(\mathrm{v} / \mathrm{v})$ glutaraldehyde (Sigma Aldrich, USA) in $0.1 \mathrm{M}$ phosphate buffer for $2 \mathrm{~h}$ at room temperature. Then, the cells were dehydrated in a graded ethanol series $(50 \% \mathrm{v} / \mathrm{v}$, $70 \% \mathrm{v} / \mathrm{v}, 80 \% \mathrm{v} / \mathrm{v}, 90 \% \mathrm{v} / \mathrm{v}$ and $95 \% \mathrm{v} / \mathrm{v}$ ) for $15 \mathrm{~min}$ each session, followed by the dehydration step (twice) in $100 \%$ ethanol for $30 \mathrm{~min}$. The cover slips containing the cells were air dried at room temperature for $30 \mathrm{~min}$, mounted on stubs and coated with gold for $15 \mathrm{~s}$. The specimens were then examined through SEM (Live Stereoscopic VPSEM; Hitachi Japan) (Ida Muryany et al. 2016).

\section{STATISTICAL ANALYSIS}

SPSS version 21 was used for the statistical analyses of the MTT assay and adhesion scores. The data were evaluated using the one-way analysis of variance followed by the Tukey test with the significant value were set at $P<0.05$.

\section{RESULTS AND DISCUSSION}

\section{CYTOTOXICITY ACTIVITY OF LACTOBACILLUS STRAINS ON INTESTINAL CELLS}

Studying the safety of the isolates against intestinal cells before they are utilized as probiotics is important to ensure probiotics would not harm and affect health of consumers. The viability of the intestinal cells exposed to Lactobacillus strains; L8, L20 and S1, is shown in Figure 1 . The results obtained indicated the viability of both the HT-29 and CCD-18Co cells incubated with all Lactobacillus strains compared with the control (Figure 1). No cytotoxic effects were observed on both cell lines following the 24 $\mathrm{h}$ incubation at $10^{9}, 10^{8}, 10^{7}, 10^{6}, 10^{5}$ and $10^{4} \mathrm{CFU} \mathrm{\textrm {mL } ^ { - 1 }}$ concentrations of the Lactobacillus strains used. The viability of both cells treated with all probionts at various concentrations showed no significant difference $(P>0.05)$ from the untreated cells (control). Similarly, the statistical analysis of the different strains of Lactobacillus also showed no significant difference $(P>0.05)$ in the viability of both intestinal cells. MTT (3-(4, 5-Dimethylthiazol2-yl)-2, 5-diphenyltetrazolium bromide) assay has been widely used to screen the cytotoxic potential of various compounds of interest. MTT assay is reliable, non-time consuming, inexpensive and always used as the preliminary screening method for the measurement of cell viability and membrane integrity (Sylvester 2011). MTT assay is based on the ability of an active dehydrogenase enzyme to reduce the tetrazolium yellow substrate into formazan dark blue crystals. The reduction serves as an index of living, metabolically active cells (Mosmann 1983). Our results showed that no cytotoxic effects were observed in both intestinal cell lines following incubation with all Lactobacillus strains.

Similar results were also described by Rossella et al. (2009) following the incubation of Caco-2 cells with L. plantarum. No significant effect on the viability of the cells was observed after the 12, 24 and $48 \mathrm{~h}$ treatment, but an increase in the viability of intestinal epithelial cells was observed instead. Our results agreed with the earlier observation by Mario et al. (2014) that L. plantarum strain PCS20 and strain PCS26 had no toxic effects on the HIEC and HUIEC cell lines. By contrast, Ewaschuk et al. 


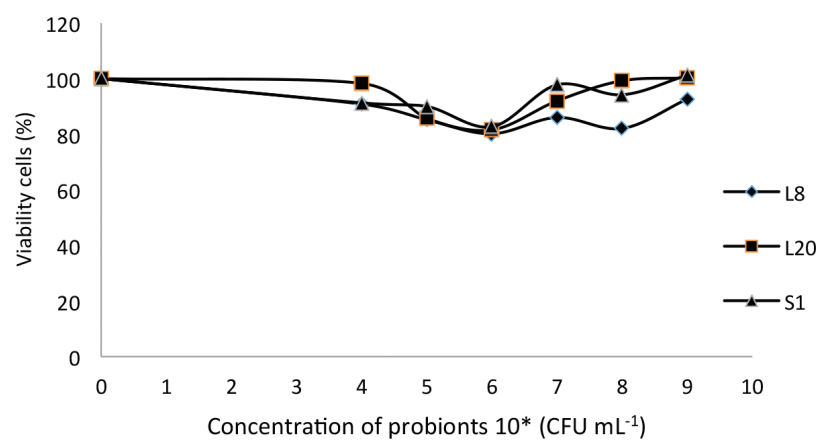

b

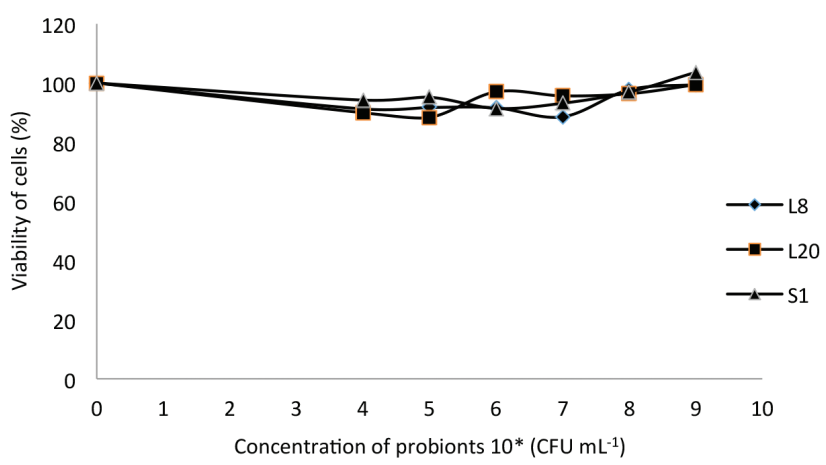

FIGURE 1. Cytotoxic effects of probionts Lactobacillus strains on (a) HT-29 cells and (b) CCD-18Co cells treated with different concentrations of probionts for $24 \mathrm{~h}$. The cytotoxicity activity was determined using the MTT assay at an optical density of $570 \mathrm{~nm}$. No significant different $(P>0.05)$ was observed in the viability of both cells treated with all probionts at various concentrations with untreated cells (control) and no significant difference $(P$ $>0.05$ ) was also observed in the viability of both intestinal cells among different strains of Lactobacillus

$\neq$ L8, L. plantarum strain L8; L20, L. plantarum strain L20; S1, L. pentosus strain S1

(2006) reported that L. plantarum, L. casei, B. longum, Streptococcus thermophilus and Bifidobacterium breve reduced the viability and induced the apoptosis of HT-29 and Caco- 2 cells following a $24 \mathrm{~h}$ treatment. According to Hojjat et al. (2014), the toxic effects and positive role of lactic acid bacteria are strain dependent and vary on intestinal cells, but the mechanism of these bacteria is still poorly understood. However, no study on the cytotoxic activities of L. pentosus has been found in previous literature.

\section{ADHESION ABILITY OF LACTOBACILLUS STRAINS ON INTESTINAL CELLS USING ADHESION ASSAY}

The quantitative binding of the Lactobacillus strains on the HT-29 and CCD-18Co cells was determined by direct microscopic examination using Giemsa staining (Figures 3 and 4). The results indicated that all the Lactobacillus strains tested were categorized as strongly adhesive because more than 100 bacteria were adhered on the cells in 20 randomly selected microscopic fields (Figure 2). The highest level of adherence was observed with L20, followed by $\mathrm{L} 8$ and then $\mathrm{S} 1$. Both the $\mathrm{L} 20$ and $\mathrm{S} 1$ strains presented higher adherence to CCD-18Co cells than to HT29 cells. Figure 2 shows that the adhesion scores of both cells treated with L8 were significantly different $(P<0.05)$ from that of the untreated cells. No significant difference $(P>0.05)$ was observed between the HT-29 and CCD-18Co cells. However, the adhesion scores of L20 and S1 on the CCD-18Co cells were significantly different $(P<0.05)$ in all groups of treatment. The mucosal of the intestine absorbs essential nutrients from the lumen for the body and produces mucous and cytokines with protective and signaling characteristics (Artis 2008). Therefore, probiotics should adhere onto the mucosal surfaces and then interact with the host surroundings. Adhesion is a complex route with multistep processes involving both non-specific mechanisms and a specific ligand receptor (An \& Friedman 2000). Our findings show that the adhesion scores of all bacteria tested indicates excellent abilities to adhere and colonize on both intestinal cells (Figures 3 and 4) according to the classification by Jacobsen et al. (1999). The average numbers of bacteria adhering to the intestinal cells were greater than 100 bacteria/20 microscopic fields. This finding is similar to that obtained by Raj et al. (2011) using the isolates from L. plantarum Lp91 and L. plantarum Lp9. Both strains were the most adhesive, whereas $L b$. delbrueckii $\mathrm{CH} 4$ showed the least adhesion activity among the isolates based on the same classification suggested by Jacobsen et al. (1999) on HT- 


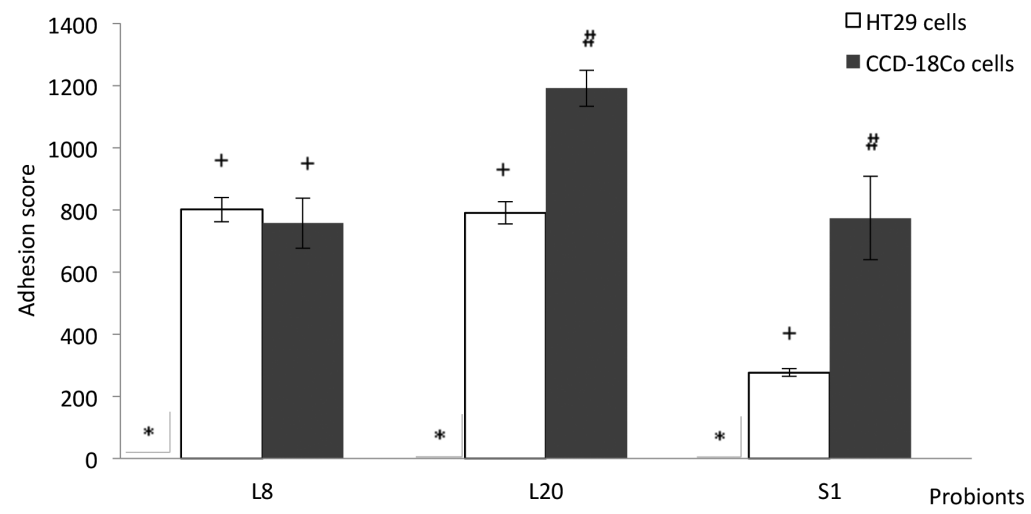

FIGURE 2. Adhesion scores of Lactobacillus strains isolated from Malaysian fermented fish to HT29 and CCD-18Co cells. Different symbols on the bar indicate significant differences at $P<0.05$. Symbol (*) indicates untreated cells which means no adhesion score

$\neq$ L8, L. plantarum strain L8; L20, L. plantarum strain L20; S1, L. pentosus strain S1

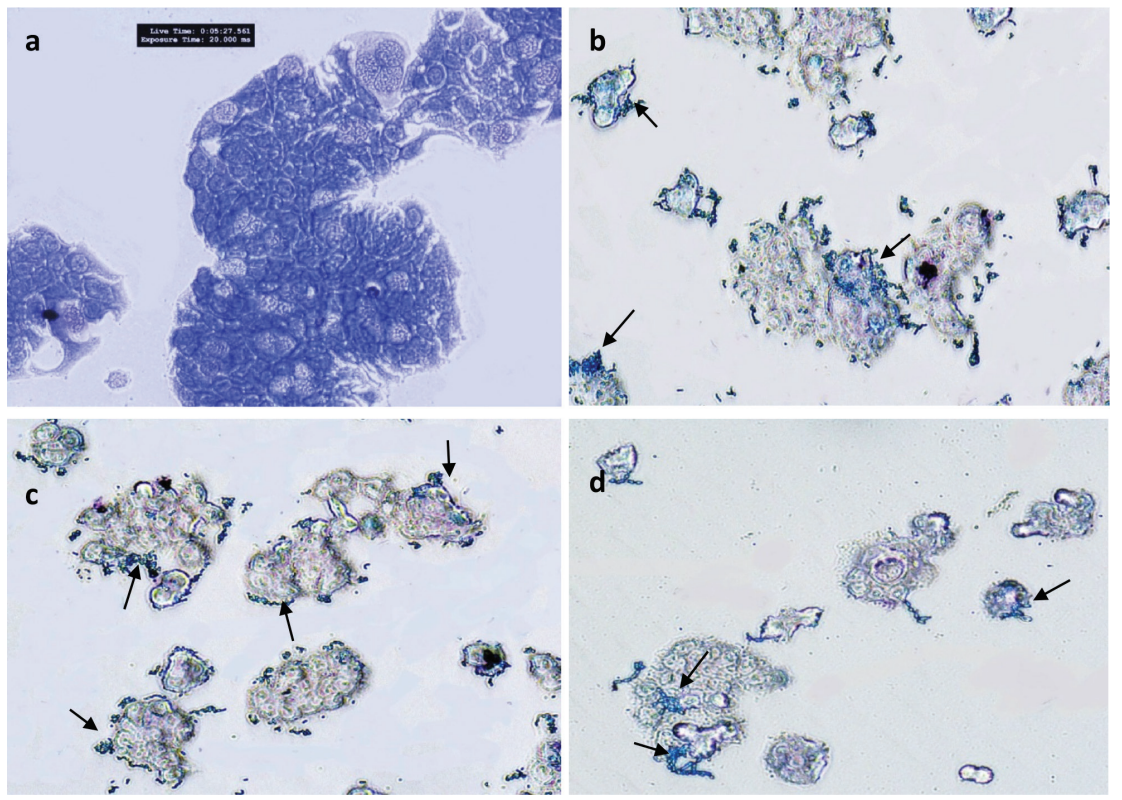

FIGURE 3. Arrows indicate the adhesion of Lactobacillus strains on HT-29 cell lines observed under an inverted microscope $(40 \times)$ following staining with Giemsa stain (a) Untreated HT-29 cells,

(b) L. plantarum strain L8, (c) L. plantarum strain L20 and (d) L. pentosus strain S1

29 and Caco 2 cell lines. The previous study conducted by Pringsulaka et al. (2015) also showed that the L.plantarum strain P6 exhibited an excellent ability to adhere to COLO 205 cell lines as observed using light microscopy with Gram staining. In addition, Wang et al. (2009) reported that L. plantarum $\mathrm{L} 2$ was the most adhesive strain to adhere to IEC-6 and CaCo- 2 cells.

Normal microbiota and pathogenic microorganisms have been shown to produce specific compounds that are also involved in their adhesion activity to epithelial host cells. According to a previous report by Otero and NaderMacias (2007), various macromolecules called adhesins, which could cause an excellent ability to adhere to intestinal epithelium, were characterized in Lactobacillus. The different amounts of adhesins produced by Lactobacillus generate different rates of adhesion activity for different strains. Chauviere et al. (1992) also reported that only some strains of Lactobacillus were able to adhere to intestinal epithelium and they varied within the same species. Our results also showed that Lactobacillus strains could also be regarded to have an excellent adhesion property to act as potential probiotics.

\section{ADHESION PATTERN OF LACTOBACILLUS STRAINS ON CELL LINES OBSERVED USING SCANNING ELECTRON MICROSCOPY}

The electron microphotographic images obtained from the SEM illustrated the adhesion of Lactobacillus strains on 


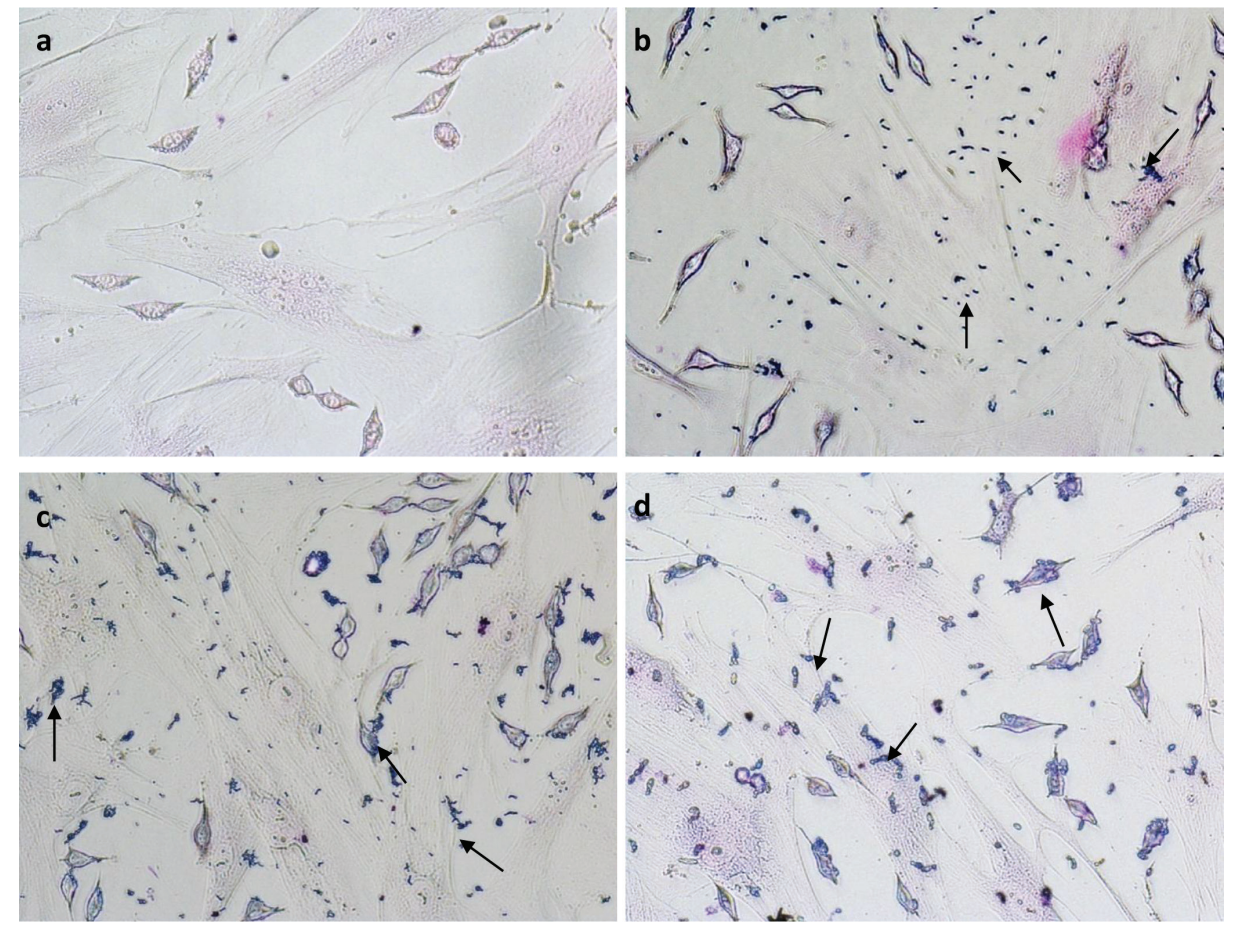

FIGURE 4. Arrows indicate the adhesion of Lactobacillus strains on CCD-18Co cell lines observed under an inverted microscope (40x) following staining with Giemsa stain (a) Untreated CCD-18Co cell, (b) L. plantarum strain L8, (c) L. plantarum strain L20 and (d) L. pentosus strain S1

the surfaces of HT-29 (Figure 5) and CCD-18Co intestinal cells (Figure 6). These three strains demonstrated an autoaggregative pattern and physically interacted with each other as a group on the surface and on the side of the epithelial cells. Photographs also showed that the attachment of Lactobacillus strains onto both intestinal cells did not cause any cell damage or epithelium loss. Both HT-29 and CCD-18Co intestinal cells remained intact with no morphological shrinkage observed. Many protruding structures and abundant cilia could be seen on the surface of the CCD-18Co cells. The bacteria showed good attachment on the surface of the cells, thus suggesting that they interacted well with the host (Pavelka \& Roth 2015). Under the SEM observation, all Lactobacillus strains tested showed the ability to adhere to both HT-29 and CCD-18Co intestinal cells. All strains were bound to both cells through the formation of attachments, which were characterized by the association with the external protein S-layer (Frece et al. 2005) and production of lipoteichoic acid by adherent bacteria (Tannock 1990). All Lactobacillus strains manifested on both cell lines with the same adhesive qualities and remained stable in situ. Antonio et al. (2005) claimed that LAB including Lactobacillus could form a biofilm on the mucosal surfaces that could confer a physical barrier for non-desirable microorganisms. Furthermore, LAB also adhered to the epithelial layer covered by mucus on the intestinal mucosa (Collado et al. 2007).

In our microscopic observation, SEM images also showed an autoaggregative pattern of bacterial attachment. Autoaggregation is a reversible congregation and accumulation of bacterial cells belonging to the same strain on the host cells (Gobin 2011). A previous study demonstrated that autoaggregation was strongly related to adhesion (Del Re et al. 2000) and that the adherence to intestinal mucosa was the first step to intestinal colonization and could enhance the protection of gastrointestinal tract (Alander et al. 1999). Our results were similar to those of Tamara et al. (2012), in which three L. plantarum strains (S1, A and B) showed high autoaggregation percentages of more than $80 \%$. The attachment of the bacteria on the intestinal cells are very good to prevent their detachment which can caused by strong forces. Therefore, the bacteria could remain adhered to the intestinal cells even after tough and long treatments during the preparation of the samples (Otero \& Nader-Macias 2007). As conclusion, probiotic bacteria with strong adherence activity onto intestinal cells could have good interaction with the host then will show excellent immunomodulatory activity.

\section{CONCLUSION}

In the current study, the potential probiotic of $L b$. plantarum strain L8, Lb. plantarum strain L20 and Lb. pentosus strain S1 had demonstrated no cytotoxic effects towards both HT-29 human adenocarcinoma cells and CCD-18Co human colon fibroblast cells. Moreover, these Lactobacillus strains have shown high ability to adhere to both intestinal cells as determined using the Giemsa staining and observed under inverted microscopy. Scanning electron microscopy also showed the pattern of adhesion of all Lactobacillus 

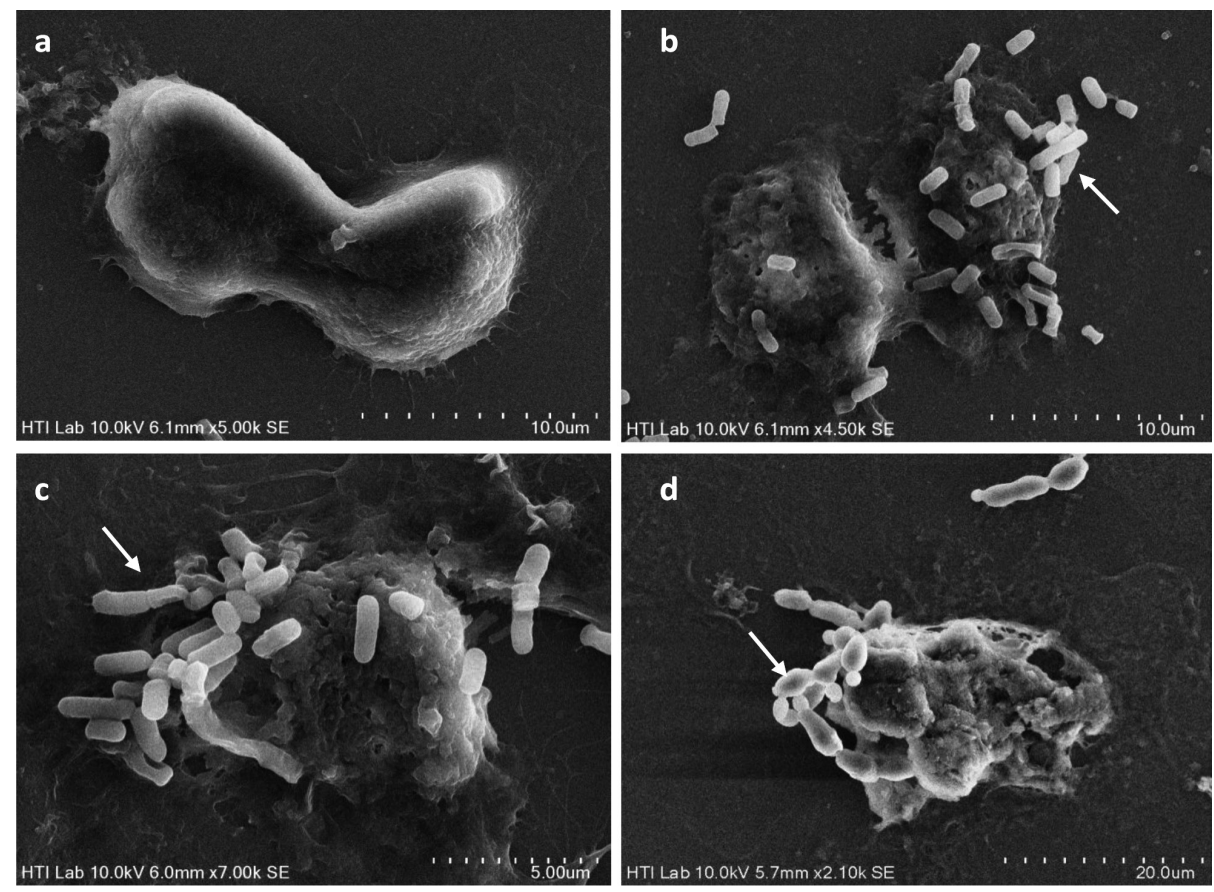

FIGURE 5. Adhesion patterns of Lactobacillus strains on the surface of HT-29 intestinal cells by SEM. Lactobacillus strain adheres and aggregates to the surface of cells (a) Untreated HT-29 cells, (b) L. plantarum strain L8, (c) L. plantarum strain L20, and (d) L. pentosus strain S1. Arrows indicate the attachment and autoaggregative pattern of Lactobacillus strains on HT-29 cells
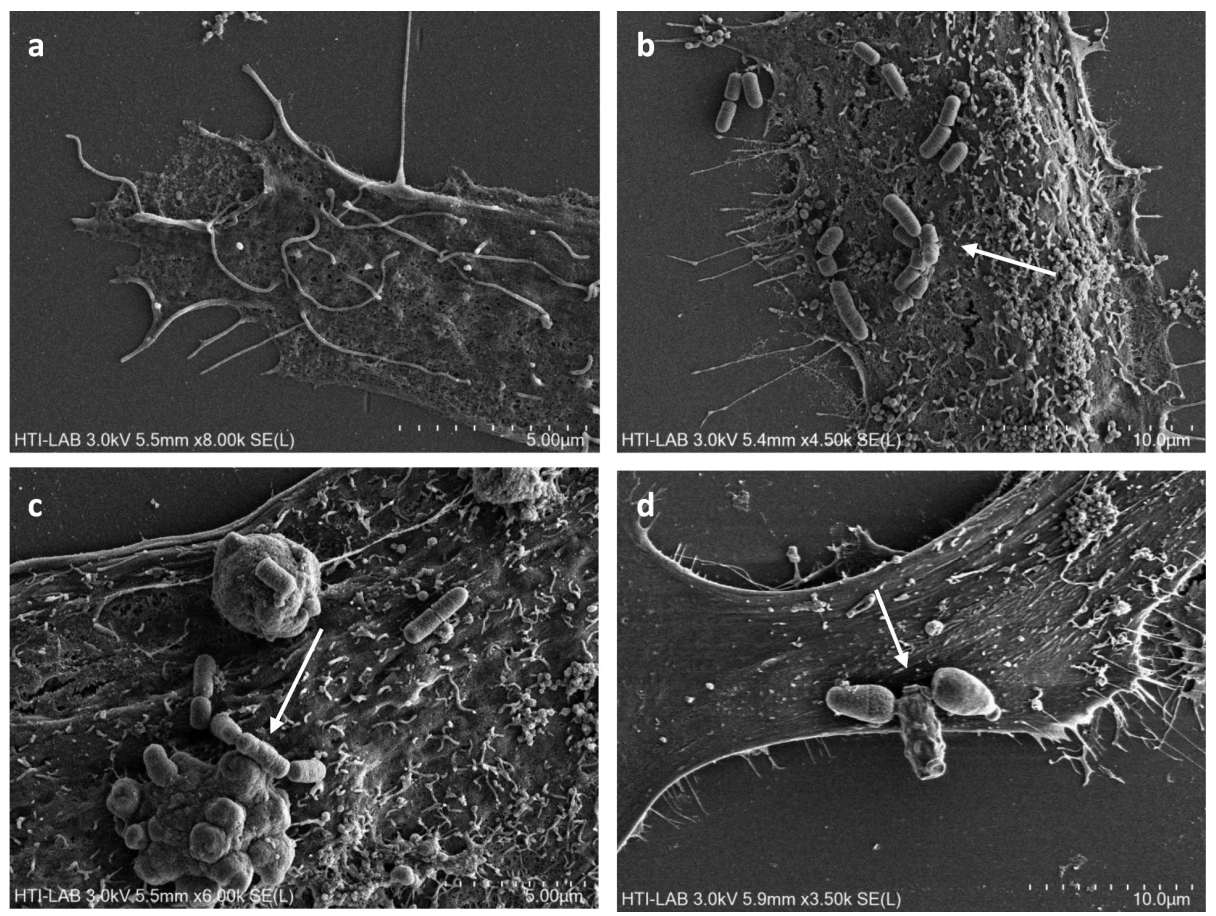

FIGURE 6. Adhesion patterns of Lactobacillus strains on the surface of CCD-18Co intestinal cells by SEM. Lactobacillus strain adhered and were aggregated to the surface of cells (a) Untreated CCD-18Co cells,

(b) L. plantarum strain L8, (c) L. plantarum strain L20, and (d) L. pentosus strain S1. Arrows indicate the attachment and autoaggregative pattern of Lactobacillus strains on CCD-18Co cells

strains could also remain stable on the surface and sides of the cells. Further studies are still needed to elucidate the mechanism behind the intimate attachment between the potential probiotic lactobacilli and intestinal cells. 


\section{ACKNOWLEDGEMENTS}

The present work was financially provided by the Ministry of Agriculture and Agro-Based Industry Malaysia (Project NH1014D071). The authors would like to thank the Histopathology Lab, Department of Diagnostic Veterinar, Faculty of Veterinar Medicine, University Putra Malaysia and Hi-Tech Instruments Sdn. Bhd. We would like to thank Ooi Mei Hong, a specialist from the Hi-tech Instruments Sdn. Bhd. for her technical support.

\section{REFERENCES}

Alander, M., Satokari, R., Korpela, R., Saxelin, M., VilpponenSalmela, T., Mattilla-Sandholm, T. \& von Wright, A. 1999. Persistence of colonization of human colonic mucosa by a probiotic strain, Lactobacillus rhamnosus $G G$, after oral consumption. Application Environmental Microbiology 65(1): 351-354.

An, Y. \& Friedman, R. 2000. Handbook of Bacterial Adhesion. Principles, Methods and Applications. Totowa: Humana Press Inc. pp. 1-27.

Antonio, M.A., Rabe, L.K. \& Hillier, S.I. 2005. Colonization of the rectum by Lactobacillus species and decreased risk of bacterial vaginosis. Journal of Infectious Disease 192(3): 394-398.

Artis, D. 2008. Epithelial-cell recognition of commensal bacteria and maintenance of immune homeostasis in the gut. Nature Review Immunology 8(6): 411-420.

Ayeni, F.A., Borja, S., Bolanle, A.A., Clara, G.R.G., Abelardo, M. \& Patricia, R.M. 2011. Evaluation of the functional of Weissella and Lactobacillus isolates obtained from Nigerian traditional fermented foods and cow's intestine. International Journal of Food Microbiology 147: 97-104.

Biller, J.A., Katz, A.J., Flores, A.F., Buie, T.M. \& Gorbach, S.I. 1995. Treatment of recurrent Clostridium difficile colitis with Lactobacillus GG. Journal of Pediatric Gastroenterology \& Nutrition 21(2): 224-226.

Chang, D.E., Smalley, D.J., Tucker, D.L., Leatham, M.P., Norris, W.E., Stevenson, S.J., Anderson, A.B., Grissom, J.E., Laux, D.C., Cohen, S.P. \& Conway, T. 2004. Carbon nutrition of Escherichia coli in the mouse intestine. Proceedings of the National Academy of Sciences of the United States of America 101(19): 7427-7432.

Chauviere, G., Coconnier, M.H., Kerneis, S., Fourniat, J. \& Servin, A.L. 1992. Adhesion of Lactobacillus acidophilus strain LB to human enterocyte-like Caco-2 cells. Journal of General Microbiology 138: 1689-96.

Christensen, H.R., Frokiaer, H. \& Pestka, J.J. 2002. Lactobacilli differentially modulate expression of cytokines and maturation surface markers in murine dendritic cells. Journal of Immunology 168(1): 171-178.

Coconnier, M.H., Klaenhammer, T.R., Kerneis, S., Fourniat, S. \& Servin, A.L. 1992. Protein-mediated adhesion of Lactobacillus acidophilus BG2F04 on human enterocyte and mucus-secreting cell lines in culture. Applied and Environmental Microbiology 58(6): 2034-2039.

Collado, M.C., Meriluoto, J. \& Salminen, S. 2007. In vitro analysis of probiotic strains combinations to inhibit pathogen adhesion to human intestinal mucus. Food Research International 40(5): 629-636.

Collado, M.C., Meriluoto, J. \& Salminen, S. 2007. Role of commercial probiotic strains against human pathogen adhesion to intestinal mucus. Letter of Applied Microbiology 45(4): 454-460.

Del Re, B., Sgorbati, B., Miglioli, B. \& Palenzona, D. 2000. Adhesion, autoaggregation and hydrophobicity of 13 strains of Bifidobacterium longum. Letter of Applied Microbiology 31(6): 438-442.

Ewaschuk, J.B., Walker, J.W., Diaz, H. \& Madsen, K.L. 2006. Bioproduction of conjugated linoleic acid by probiotic bacteria occurs in vitro and in vivo in mice. The Journal of Nutrition 136(6): 1483-1487.

FAO/WHO. 2002. Guidelines for the evaluation of probiotics in food. Report of a Joint FAO/WHO Working Group on Drafting Guidelines for the Evaluation of Probiotics in Food. pp. 1-11.

Frece, J., Kos, B., Svetec, I.K., Zgaga, Z., Mrsa, V. \& Suskovic, J. 2005. Importance of S-layer proteins in probiotic activity of Lactobacillus acidophilus M92. Journal of Applied Microbiology 98(2): 285-292.

Gobin, I. 2011. The protective role of lactic acid bacteria to systemic Salmonella enterica serotype Typhimurium infection in mice. PhD, University of Zagreb (Unpublished).

Ghani, M.K.A., Hany Sady, S.R., Sahalan, A.Z., Lian, H.H., Nordin, A., Suboh, Y. \& Ahmad, N. 2018. Antimicrobial efficacy against acanthamoeba isolates from clinical cases. International Medical Journal 25(2): 112-115.

Gibson, G.R., Saveedra, J.M., MacFarlane, S. \& MacFarlane, G.T. 1997. Probiotics and intestinal infections. In Probiotic. 2: Applications and Practical Aspects edited by Fuller, R. New York: Chapman \& Hall. pp. 10-39.

Hilde, M., Merete, H.H. \& Judith, N.A. 2003. Growth and metabolism of selected strains of probiotic bacteria in milk. International Journal of Food Microbiology 87(1-2): 17-27.

Hojjat, S.A., Fatemah, M., Hossain, F. \& Maryam, M. 2014. Effects of Lactobacillus plantarum A7 with probiotic potential on colon cancer and normal cells proliferation in comparison with a commercial strain. Iran Journal Basic of Medical Science 17(10): 815-819.

Holm, F. 2003. Gut health and diet: The benefits of probiotic and prebiotics on human health. The World of Food Ingredients 2: $52-55$.

Ida Muryany, M.Y., Ina Salwany, M.Y., Ghazali, A.R., Hing, H.L. \& Nor Fadilah, R. 2017. Identification and characterization of the lactic acid bacteria isolated from Malaysian fermented fish (Pekasam). International Food Research Journal 24(2): 868-875.

Ida Muryany, M.Y., Nor Fadilah, R., Ina Salwany, M.Y., Ahmad Rohi, Mohd Zamri, S., Kaswandi, M.A., Ahmad Zorin, S. \& Hing, H.L. 2016. Evaluation of cells integrity using different fixation time by scanning electron microscopy. International Journal of Biosciences 9(4): 236-241.

Isolauri, E., Sutas, Y., Kankaapaa, P.,Arvilommi, H. \& Salminen, S. 2001. Probiotics: Effects of immunity. The American Journal of Clinical Nutrition 73: 444S-450S.

Ivec, M., Botic, T., Koren, S., Jakobsen, M., Weingartl, H. \& Cencic, A. 2007. Interactions of macrophages with probiotic bacteria lead to increased antiviral response against vesicular stomatitis virus. Antiviral Research 75(3): 226-274.

Jacobsen, C.N., Rosenfeldt, N.V., Hayford, A.E., Moller, P.L., Michaelsen, K.F. \& Paerregaard, A. 1999. Screening of probiotic activities of forty-seven strains of Lactobacillus spp. by in vitro techniques and evaluation of the colonization ability of five selected strains in humans. Applied and Environmental Microbiology 65(11): 4949-4956. 
Kopp-Hoolithan, L. 2001. Prophylactic and therapeutic uses of probiotics: A review. Journal of the American Diet Association 101(2): 229-238.

Lee, Y.K., Lim, C.Y., Teng, W.L., Ouwehand, A.C., Tuomola, E.M. \& Salminen, S. 2000. Quantitative approach in the study of adhesion of lactic acid bacteria to intestinal cells and their competition with enterobacteria. Applied and Environmental Microbiology 66(9): 3692-3697.

Lee, Y.Y., Hassan, S.A., Ismail, I.H., Chong, S.Y., Raja Ali, R.A., Amin Nordin, S. \& Majid, N.A. 2017. Gut microbiota in early life and its influence on health and disease: A position paper by the Malaysian Working Group on Gastrointestinal Health. Journal of Paediatrics and Child Health 53(12): 1152-1158.

Liong, M.T. 2008. Roles of probiotics and prebiotics in colon cancer prevention: Postulated mechanisms and in vivo evidence. International Journal of Molecular Science 9: 854-863.

Margit, P. \& Jurgen, R. 2015. Functional Ultrastructure: Atlas of Tissue Biology and Pathology. 3rd ed. London: Springer.

Mario, G., Lidija, G., Martin, T., Mauro, P., Carina, P.K., Dejan, S., Pavel, S., Tomaz, L. \& Avrelija, C. 2014. Improvement of lipid profile by probiotic/protective cultures: Study in a noncarcinogenic small intestinal cell model. New Microbiologica 37: 51-64.

Mosmann, T. 1983. Rapid colorimetric assay for cellular growth and survival: Application to proliferation and cytotoxicity assays. Journal of Immunological Methods 65(1-2): 55-63.

Nader-Macias, M.E.F., Oscana, V.S., Juarez Tomas, M.S. \& Silva de, R.C. 2007. Fundamentas biologicos, procesos y biotechnologia de Bacterias Lacticas edited by CSIC.

Otero, M.C. \& Nader-Macias, M.E. 2007. Lactobacillus adhesion to epithelial cells from bovine vagina. Communicating Current Research and Educational Topics and Trends in Applied Microbiology, edited by Mendez-Vilas, A. Spain: Formatex. pp. 749-757.

Pavelka, M. \& Roth, J. 2015. Functional Ultrastructure: Atlas of Tissue Biology and Patology. 3rd ed. Vienna: Springer-Verlag. DOI 10. 1007/978-3-7091-1830-6_1.

Pringsulaka, O., Rueangyotchanthana, K., Suwannasai, N., Watanapokasin, R., Amnueysit, P., Sunthornthummas, S., Sukkhum, S., Sarawaneeyaruk, S. \& Rangsiruji, A. 2015. In vitro screening of lactic acid bacteria for multi-strain probiotics. Livestock Science 174: 66-73.

Raj, K.D., Yudhishthir, S.R., Virendar, K.B. \& Sunita, G. 2011. Assessing the adhesion of putative indigenous probiotic lactobacilli to human colonic epithelial cells. Indian Journal Medical Research 134: 664-671.

Ren, D., Li, C., Qin, Y., Yin, R., Du, S., Ye, F., Liu, C., Liu, H., Wang, M., Li, Y., Sun, Y., Li, X., Tian, M. \& Jin, N. 2014. In vitro evaluation of the probiotic and functional potential of Lactobacillus strains isolated from fermented food and human intestine. Anaerobe 30: 1-10.

Rossella, P., Caterina, R.C., Sabato, S., Nello, M. \& Antonietta, R. 2009. Immunomodulatory effects of Lactobacillus plantarum on human colon cancer cells. International Immunopharmacology 9: 1265-1271.

Sylvester, P.W. 2011. Optimization of the tetrazolium dye (MTT) colorimetric assay for cellular growth and viability. Methods in Molecular Biology 716: 157-168.

Tamara, J., Jadranka, F., Maja, A. \& Ivana, G. 2012. Aggregation ability of potential probiotic Lactobacillus plantarum strains. Original Science Paper Vol. 6: 1/2012.
Tannock, G. 1990. The microecology of lactobacilli inhabiting the gastrointestinal tract. Advance Microbial of Ecology 11: 147-171.

Thapa, N., Pal, J. \& Tamang, J.P. 2006. Phenotypic identification and technological properties of lactic acid bacteria isolated from traditionally processed fish product of Eastern Himalayas. International Journal of Food Microbiology 107: 33-38.

Wang, B., Li, J., Li, Q., Zhang, H. \& Li, N. 2009. Isolation of adhesive strains and evaluation of the colonization and immune response by Lactobacillus plantarum L2 in the rat gastrointestinal tract. International Journal of Food Microbiology 132: 59-66.

Yap, W.B., Ahmad, F.M., Lim, Y.C. \& Zainalabidin, S. 2016. Lactobacillus casei strain $\mathrm{C} 1$ attenuates vascular changes in spontaneously hypertensive rats. Korean Journal of Physiology and Pharmacology 20(6): 621-628.

Ida Muryany, Ahmad Rohi Ghazali \& Nor Fadilah Rajab*

Biomedical Science Programme

Faculty of Health Sciences

Universiti Kebangsaan Malaysia

Jalan Raja Muda Abdul Aziz

50300 Kuala Lumpur, Federal Territory

Malaysia

Hing Hiang Lian

Environmental Health Programme

Faculty of Health Sciences

Universiti Kebangsaan Malaysia

Jalan Raja Muda Abdul Aziz

50300 Kuala Lumpur, Federal Territory

Malaysia

Ina-Salwany

Aquaculture Department

Faculty of Agriculture

Universiti Putra Malaysia

43400 UPM Serdang, Selangor Darul Ehsan

Malaysia

Mohd Zamri Saad

Veterinary Diagnostic Department

Faculty Veterinar Medicine

Universiti Putra Malaysia

43400 UPM Serdang, Selangor Darul Ehsan

Malaysia

Ida Muryany

School of Biology

Faculty of Applied Sciences

Universiti Teknologi MARA

40450 Shah Alam, Selangor Darul Ehsan

Malaysia

*Corresponding author; email: nfadilah@ukm.edu.my

Received: 22 February 2018

Accepted: 5 June 2018 